\title{
Prevalence of Chronic Obstructive Pulmonary Disease in General Practice patients in the Central Region of Portugal
}

\author{
JÉSSICA ANDREIA RICARDO ${ }^{1, A-G}$, JOSÉ AUGUSTO SIMÕES 2-4, A-G, LU \\ ORCID ID: 0000-0002-3568-4583 \\ ORCID ID: 0000-0003-2264-7086 \\ ORCID ID: 0000-0002-9343-2827 \\ ${ }^{1}$ Faculty of Medicine, University of Coimbra, Coimbra, Portugal \\ ${ }^{2}$ Faculty of Health Sciences, University of Beira Interior, Covilhã, Portugal \\ ${ }^{3}$ University Clinic of General Practice and Family Medicine of the University of Coimbra, Coimbra, Portugal \\ ${ }^{4}$ CINTESIS - Centre for Research in Health Technologies and Service, Porto, Portugal \\ ${ }^{5}$ CEISUC - Centre for Health Studies and Research of the University of Coimbra, Coimbra, Portugal
}

A - Study Design, B - Data Collection, C - Statistical Analysis, D - Data Interpretation, E - Manuscript Preparation, F - Literature Search, G - Funds Collection

Summary Background. COPD is a common worldwide condition associated with morbidity and mortality. Its symptoms can be easily overlooked, accounting for an elevated level of under-recognition and under-diagnosis. Knowledge of the prevalence of COPD and the significance of its associated factors in the population enables better management of medical resources.

Objectives. To establish the prevalence of COPD in General Practice patients in the Central Region of Portugal and analyze the correlation with associated factors.

Methods. Cross-sectional study of patients' data with COPD (R95, International Classification for Primary Care 2), anonymously gathered from the official database of the Central Health Administration of Portugal.

Results. Out of 937,817 individuals, 24,148 patients were identified with COPD, a prevalence of 2.57/100,000. $73.7 \%$ were above 65 years of age, and $60.2 \%$ were males. BMI was recorded in $60.2 \%$ patients, FEV $(\%)$ in $8.0 \%$, and smoking pack-years in $37.1 \%$. Age and BMI were significantly negatively correlated $(\rho=-0.032, p<0.001)$, with the same occurring between age and FEV ${ }_{1}(\%)(\rho=-0.073, p<$ 0.05). A strong association of COPD with male gender and older age groups was found.

Conclusions. The prevalence of COPD was significantly higher in males, and age was identified as a risk factor for this condition. Higher age was non-significantly associated with lower $\mathrm{FEV}_{1}(\%)$ and significantly associated with BMI. The lack of e-records calls for an improvement.

Key words: chronic obstructive pulmonary disease, prevalence, primary health care, smoking, age distribution, gender identity.

Ricardo JA, Simões JA, Santiago LM. Prevalence of Chronic Obstructive Pulmonary Disease in General Practice patients in the Central Region of Portugal. Fam Med Prim Care Rev 2021; 23(2): 220-223, doi: https://doi.org/10.5114/fmpcr.2021.105930.

\section{Background}

Chronic Obstructive Pulmonary Disease (COPD) is an obstructive pulmonary pathology characterized by a not fully reversible and progressive limitation of the airflow.

This pathology is described as a global health problem, with an elevated level of significance conferred by its high mortality and morbidity, as it is currently listed as the fourth leading cause of death worldwide [1, 2]. By the end of 2020, COPD is projected to be the third leading cause of death worldwide, with the disease burden constantly increasing over the next decades due to aging of the population, as well as continuous exposure to COPD-related risk factors [3, 4].

The genesis of this chronic disease is the persistent inflammatory response of the airspaces, responsible for the irreversible alteration of its proprieties, leading to remodeling and consequent deformation, causing a progressive decline of the patient's pulmonary function $[5,6]$.

The typical findings in this pathology are a persistent decrease of the percentage of forced expiratory volume in the first second $\mathrm{FEV}_{1}(\%)$ during spirometry, accompanied by respiratory symptoms, usually in the form of a persistent cough with sputum (chronic phlegm) $[7,8]$.

In Portugal, the prevalence of this condition is estimated to be 9 to $14 \%$ [9], concomitant with an elevated level of the under-diagnosed population (86.2\%) [10], while worldwide, the prevalence of COPD was estimated at $11.7 \%$ in 2010 [11].
Smoking is a leading risk factor associated with COPD. Smokers have a higher prevalence of respiratory symptoms, higher annual decline in $\mathrm{FEV}_{1}(\%)$ and higher mortality associated with the disease when compared to non-smokers [12]. Other causes like bad breathing atmosphere and chronic dust exposure can be added [8-13].

Aging is also widely referred to as a risk factor for COPD, but whether this is due to aging of the airways and parenchyma itself or due to the cumulative effects of exposures throughout life still remains controversial [13].

Gender differences have also been described in COPD, with past studies showing a higher prevalence amongst males; however, more recent studies have shown a tendency toward a normalization of the prevalence among both genders. This phenomenon is largely attributed to the change in tobacco smoking patterns, with an increase of tobacco smoking among females throughout the years [14]. The clinical presentation of COPD can also vary according to gender, with females being less likely than males to report dyspnea as the main symptom $[15,16]$. COPD is listed as the most probable diagnosis more often in males than in females, and thus it is associated with a greater level of under-diagnosis among females, indicating the great importance of spirometry in the diagnosis of this condition [17]. Females have also been described as more susceptible to smoke exposure, showing a greater pulmonary function decline associated with lower smoking exposure when compared to males [18]. 
Lung function specific measurements, such as $\mathrm{FEV}_{1}(\%)$, are widely used as predictors of mortality in COPD, as well as in the general population [19-22]. However, other factors have been described as good predictors in the mortality associated with this condition [23], with prognostic tools such as the BODE index measuring the patient's BMI, degree of airflow obstruction, dyspnea and exercise capacity, showing better results in predicting the risk of death in COPD patients than using $\mathrm{FEV}_{1}(\%)$ alone $[24,25]$.

There are estimations of the prevalence of COPD in the Portuguese population based on an analysis of clusters [10]. Portuguese General Practitioners in Central Portugal work daily with an informatics program for e-health records to classify diseases, namely COPD using the ICPC2, so making it possible to determine COPD's prevalence.

\section{Objectives}

1. To establish the prevalence of "Chronic Obstructive Pulmonary Disease (R95)" in the area of the Regional Health Administration of Central Portugal.

2. To characterize socio-demographics of COPD patients such as: age, gender, $\mathrm{FEV}_{1}(\%), \mathrm{BMI}$ and smoking burden.

\section{Material and methods}

This was a cross-sectional study of data gathered on December $31^{\text {st }}$ of 2018 . The study was approved by the ethics committee of the Regional Health Administration of Central Portugal. Data was granted by the IT department of the Regional Health Administration of Central Portugal.

Data referring to age, gender, smoking burden, $\operatorname{FEV}_{1}(\%)$ and $\mathrm{BMI}$ from patients 40 years of age or more classified with the ICPC-2 of "Chronic Obstructive Pulmonary Disease (R95)" was collected anonymously.

All statistical analyses were performed using the Statistical Package for the Social Sciences (SPSS), version 25. Descriptive statistics included mean and standard deviation for continuous variables and absolute and relative frequency for categorical variables. Distribution normality was assessed using the Kolmogorov-Smirnov test. Chi-square and Mann-Whitney tests were used to establish associations and differences between variables, respectively. For correlation of variables, we used Spearman's correlation coefficient and Partial Correlations to adjust for gender. Correlations were considered very strong when a coefficient was greater than 0.90 , strong if between 0.70 and 0.90 , moderate if between 0.50 and 0.70 , weak if between 0.30 and 0.50 and very weak if less than 0.30 . The results were significant at $p<0.05$.

\section{Results}

Out of of 937,817 individuals, 24,148 patients were classified as ICPC-2 "Chronic Obstructive Pulmonary Disease (R95)" and were included in this study. The prevalence of COPD was $2.57 / 100,000$. The characteristics of the participants are shown in Table 1. Regarding gender, $60.2 \%(14,544)$ were male, and $39.8 \%(9,604)$ were female. The mean age was $71.9 \pm 11.6$ years, and the majority were above 65 years of age $(73.7 \% ; n=$ $17,805)$. The Baixo Mondego region was the most represented in our sample (20.1\%; $n=4,853$ ). Out of the 24,148 patients, only 15,470 had BMI records, 1,921 had $\mathrm{FEV}_{1}(\%)$, and 8,957 had pack-years registered. Mean BMI was $28.6 \pm 7.1 \mathrm{~kg} / \mathrm{m}^{2}$, mean $\mathrm{FEV}_{1}(\%)$ was $62.8 \pm 29.8$ and mean pack-years was $10.3 \pm 22.0$.

Table 2 represents the gender comparison of the collected data. Females with COPD were significantly older (73.5 years old) compared to males (70.9 years old; $p<0.001$ ), and the latter was significantly overrepresented in the age group below 65 years of age $(28.2 \% ; p<0.001)$. Gender was associated with the participant's region $(p<0.001)$. Female patients with COPD had a higher median $\mathrm{BMI}(\mathrm{M}=29.3 ; p<0.001)$ and $\mathrm{FEV}_{1}(\%)(\mathrm{M}=$ $66.1 ; p=0.001)$ but lower median pack-years $(M=3.4 \pm 11.5)$ compared to males.

\begin{tabular}{|c|c|c|}
\hline Characteristics & $n$ & $\%(n)$ or Mean \pm SD \\
\hline $\begin{array}{l}\text { Gender, } \%(n) \\
\text { male } \\
\text { female }\end{array}$ & 24,148 & $\begin{array}{l}60.2(14,544) \\
39.8(9,604)\end{array}$ \\
\hline Age (years), mean \pm SD & 24,148 & $71.9 \pm 11.6$ \\
\hline $\begin{array}{l}\text { Age group, } \%(n) \\
<65 \text { years } \\
\geq 65 \text { years }\end{array}$ & 24,148 & $\begin{array}{l}26.3(6,343) \\
73.7(17,805)\end{array}$ \\
\hline $\begin{array}{l}\text { Region, \% }(n) \\
\text { Baixo Mondego } \\
\text { Baixo Vouga } \\
\text { Beira Interior Sul } \\
\text { Pinhal Litoral } \\
\text { Dão Lafões } \\
\text { Pinhal Interior Norte } \\
\text { ULS Guarda } \\
\text { Cova da Beira } \\
\text { Pinhal Interior Sul }\end{array}$ & 24,148 & $\begin{array}{l}20.1(4,853) \\
19.0(4,586) \\
7.4(1,780) \\
14.4(3,485) \\
14.4(3,468) \\
8.0(1,930) \\
6.7(1,617) \\
6.2(1,496) \\
3.9(933)\end{array}$ \\
\hline BMI $\left(\mathrm{kg} / \mathrm{m}^{2}\right)$, mean $\pm \mathrm{SD}$ & 15470 & $28.6 \pm 7.1$ \\
\hline $\begin{array}{l}\mathrm{FEV}_{1}(\%) \text { predicted, mean } \\
\pm \mathrm{SD}\end{array}$ & 1921 & $62.8 \pm 29.8$ \\
\hline Pack-years, mean $\pm S D$ & 8957 & $10.3 \pm 22.0$ \\
\hline
\end{tabular}

$\mathrm{BMI}$ - Body Mass Index, $\mathrm{FEV}_{1}(\%)$ - Forced Expiratory Volume in the first second, $n$ - number of patients with available data, SD - standard deviation.

Table 2. Gender comparison of clinical features in patients with COPD

\begin{tabular}{|c|c|c|c|}
\hline \multirow[t]{2}{*}{ Characteristics } & \multicolumn{2}{|l|}{ Gender } & \multirow[t]{2}{*}{$p$} \\
\hline & $\begin{array}{l}\text { Male } \\
(n=14544)\end{array}$ & $\begin{array}{l}\text { Female } \\
(n=9604)\end{array}$ & \\
\hline Age (years), mean \pm SD & $70.9 \pm 11.2$ & $73.5 \pm 11.9$ & $<0.001$ \\
\hline $\begin{array}{l}\text { Age group, } \%(n) \\
\quad<65 \text { years } \\
\geq 65 \text { years }\end{array}$ & $\begin{array}{l}28.2(4,097) \\
71.8(10,447) \\
\end{array}$ & $\begin{array}{l}23.4(2,246) \\
76.6(7,358) \\
\end{array}$ & $<0.001$ \\
\hline $\begin{array}{l}\text { Region, \% }(n) \\
\text { Baixo Mondego } \\
\text { Baixo Vouga } \\
\text { Pinhal Litoral } \\
\text { Dão Lafões } \\
\text { Pinhal Interior Norte } \\
\text { Beira Interior Sul } \\
\text { ULS Guarda } \\
\text { Cova da Beira } \\
\text { Pinhal Interior Sul } \\
\end{array}$ & $\begin{array}{l}20.6(2,996) \\
19.0(2,766) \\
14.2(2,067) \\
14.1(2,048) \\
7.7(1123) \\
7.4(1074) \\
6.8(988) \\
6.9(1,004) \\
3.3(478) \\
\end{array}$ & $\begin{array}{l}19.3(1,857) \\
19.0(1,820) \\
14.8(1,418) \\
14.8(1,420) \\
8.4(807) \\
7.4(706) \\
6.5(629) \\
5.1(492) \\
4.7(455) \\
\end{array}$ & $<0.001$ \\
\hline $\begin{array}{l}\mathrm{BMI}\left(\mathrm{kg} / \mathrm{m}^{2}\right) \\
\text { mean } \pm \mathrm{SD}\end{array}$ & $28.1 \pm 6.0$ & $29.3 \pm 8.5$ & $<0.001$ \\
\hline $\begin{array}{l}\mathrm{FEV}_{1}(\%) \text { predicted, } \\
\text { mean } \pm \mathrm{SD}\end{array}$ & $61.1 \pm 27.9$ & $66.1 \pm 33.2$ & 0.001 \\
\hline Pack-years, mean \pm SD & $14.9 \pm 25.8$ & $3.4 \pm 11.5$ & $<0.001$ \\
\hline
\end{tabular}

$\mathrm{MI}$ - Body Mass Index, $\mathrm{FEV}_{1}(\%)$ - Forced Expiratory Volume in the first second, SD - standard deviation.

Mean age and BMI were highest in the Pinhal Interior Sul region and lowest in Baixo Vouga. Mean $\mathrm{FEV}_{1}(\%)$ was higher in the interior regions of Cova da Beira and Pinhal Interior do Sul and lower in the seaside locations (Pinhal Litoral and Baixo Mondego). Mean pack-years were higher in Baixo Mondego and Cova da Beira but lower in Pinhal Interior Sul and Dão Lafões. 
There were significant differences in terms of age $(p<0.001)$, $\operatorname{BMI}(p<0.001), \operatorname{FEV}_{1}(\%)(p<0.001)$ and pack-years $(p<0.001)$ between regions.

Unadjusted and adjusted correlations between continuous variables using Spearman's correlation coefficient are shown in Table 3. There were negative correlations between age, BMI and $\mathrm{FEV}_{1}(\%)$. Age and pack-years showed a positive correlation. Partial correlations controlling for gender showed a negative correlation between age and $\mathrm{FEV}_{1}(\%)\left(r_{s}=-0.065\right)$ and positive correlations between age and pack-years $\left(r_{s}=0.223\right)$ and between pack-years and BMI $\left(r_{s}=0.058\right)$. All significant correlations were deemed as very weak (coefficient $<0.3$ ).

\begin{tabular}{|c|c|c|c|}
\hline Variables (unadjusted) & Age & BMI & $\mathrm{FEV}_{1}$ \\
\hline $\mathrm{BMI}\left(\mathrm{kg} / \mathrm{m}^{2}\right)$ & $-0.032 * *$ & & \\
\hline $\mathrm{FEV}_{1}(\%)$ & $-0.073 *$ & 0.034 & \\
\hline Pack-years (greater than 0) & $0.219 * *$ & 0.005 & -0.051 \\
\hline Variables (adjusted for gender) & Age & BMI & $\mathrm{FEV}_{1}$ \\
\hline BMI $\left(\mathrm{kg} / \mathrm{m}^{2}\right)$ & 0.046 & & \\
\hline $\mathrm{FEV}_{1}(\%)$ & $-0.065^{*}$ & 0.052 & \\
\hline Pack-years (greater than 0) & $0.223 * *$ & $0.058 *$ & -0.010 \\
\hline
\end{tabular}

\section{Discussion}

We identified 24,148 patients that were classified with ICPC-2 "Chronic Obstructive Pulmonary Disease (R95)" out of 937,817 individuals, resulting in a prevalence of COPD of 2.57 per 100,000 . The calculated prevalence of COPD in the Central Region of Portugal was significantly lower than the prevalence estimated for this disease in past studies, both worldwide and in Portugal $[9,10,26-29]$. There are many aspects that can contribute to such a low prevalence in this study: the methodology used in most observational studies being different from the clinical one we used, which is based on existing records. The authors cannot confirm the realization of spirometry with set criteria for COPD diagnosis in every patient, even though the low prevalence may reflect the lack of availability of spirometry in this setting. This study was based on records of chronic patients' problems and a documented diagnosis of COPD for the calculation of the prevalence of COPD [10]. The low prevalence can be explained by lack of clinical findings, lack of ease of spirometry or even due to the lack of a doctor's interest concerning this important health topic [29].

Age was identified as a risk factor for this condition, with the age group above 65 years of age being the most represented in our population. A higher age was also associated with greater pulmonary function decline (lower $\left.\mathrm{FEV}_{1}(\%)\right)$ and lower BMI, both being criteria for a worse prognosis [19-25]. Smoking burden was also found to increase with age.

Airway obstruction for this disease was found to be more severe (with lower $\mathrm{FEV}_{1}(\%)$ ) amongst patients in seaside locations.

The prevalence was significantly higher in males, with a concomitant higher smoking burden in this gender. It is safe to assume that even though recent studies have shown a tendency toward normalization of the prevalence amongst genders [13], in the Central Region of Portugal, the prevalence of COPD was higher in males, probably due to a lack of change in smoking patterns, with smoking still being highly associated with the male gender in this area.

All the data was gathered thanks to the existence of a Primary Health Care national health database, containing information about people assisted with acute and chronic problems classified according to ICPC2 in the e-records made by doctors of General Practice/Family Medicine using the comprehensive e-platform. Despite this, there was a considerable lack of registrations regarding $\mathrm{FEV}_{1}(\%), \mathrm{BMI}$ and smoking burden in the form of pack-years for the patients classified with COPD. For $\mathrm{FEV}_{1}(\%)$ registrations, the collected data was related to spirometry results in the study year. Lack of knowledge of spirometry does not mean it has not been made some years ago. $\mathrm{FEV}_{1}(\%)$ is a highly reproductive measurement, strongly related to mortality $[22,30]$, and its registration in the clinical records of patients with COPD is highly recommended.

\section{Limitations of the study}

Although the ICPC-2 criteria for the classification of COPD [31] define the need for "objective evidence of airway obstruction, not/only partially relieved by bronchodilators", we cannot guarantee that all doctors, when classifying with ICPC-2 R95, had access to the results of spirometry according to the guidelines of the Global Initiative for Chronic Obstructive Lung Disease (GOLD) [32]. We recognize that probably not all patients who actually suffer from COPD are in this database for medical underdiagnosis, and since this is a study based on recording consultation data, we have no way of ensuring that all doctors followed the criteria expressed when classifying with the R95. Most complete diagnoses should take in consideration the pathophysiology that leads to chronic airway obstruction [33-35].

\section{Strengths}

This a large volume data study, encompassing a whole health region in Portugal.

\section{Opportunities}

To change for better the diagnosis of COPD and to have better epidemiologic data on this medical issue.

\section{Conclusions}

COPD is a pathology mostly associated with the male gender and with older age groups in the Central Region of Portugal. Smoking burden was also higher amongst males when compared to females in this region.

The calculated prevalence of COPD was considerably low in Central Portugal Primary Care databases. There is a need to improve classification, quantitatively and qualitatively, by doctors in Primary Health Care, especially for associated factors such as $\mathrm{FEV}_{1}(\%), \mathrm{BMI}$ and smoking burden.

Acknowledgements. The authors would like to thank Dr Conceição Saraiva, from the informatic services of the Regional Health Administration of Center Portugal, for being so helpful and efficient with gathering data, and Dr Denise Alexandra, for the English review of this paper.

Source of funding: This work was funded from the authors' own resources.

Conflicts of interest: The authors declare no conflicts of interest.

\section{References}

1. Lozano R, Naghavi M, Foreman K, et al. Global and regional mortality from 235 causes of death for 20 age groups in 1990 and 2010 : a systematic analysis for the Global Burden of Disease Study 2010. Lancet 2012; 380(9859): 2095-2128.

2. Quaderi SA, Hurst JR. The unmet global burden of COPD. Glob Health Epidemiol Genom 2018; 3: e4.

3. Mathers CD, Loncar D. Projections of global mortality and burden of disease from 2002 to 2030. PLoS MED 2006; 3(11): e442. 
4. López-Campos JL, Tan W, Soriano JB. Global burden of COPD. Respirology 2016; 21(1): 14-23.

5. Macnee W. Pathogenesis of chronic obstructive pulmonary disease. Clin Chest Med 2007; 28(3): 479-513.

6. Hogg JC, Timens W. The pathology of chronic obstructive pulmonary disease. Annu Rev Pathol 2009; 4: 435-459.

7. Kessler R, Partridge MR, Miravitlles M, et al. Symptom variability in patients with severe COPD: a pan-European cross-sectional study. Eur Respir J 2011; 37(2): 264-272.

8. Fletcher C, Peto R. The natural history of chronic airflow obstruction. Br Med J 1977; 1(6077): 1645-1648.

9. Blanco I, Diego I, Bueno P, et al. Geographical distribution of COPD prevalence in Europe, estimated by an inverse distance weighting interpolation technique. Int J Chron Obstruct Pulmon Dis 2018; 13: 57-67.

10. Bárbara C, Rodrigues F, Dias H, et al. Chronic obstructive pulmonary disease prevalence in Lisbon, Portugal: the burden of obstructive lung disease study. Rev Port Pneumol 2013; 19(3): 96-105.

11. Adeloye D, Chua S, Lee C, et al. Global and regional estimates of COPD prevalence: systematic review and meta-analysis. J Glob Health 2015; 5(2): 020415.

12. Kohansal $\mathrm{R}$, Martinez-Camblor $\mathrm{P}$, Agustí A, et al. The natural history of chronic airflow obstruction revisited: an analysis of the Framingham offspring cohort. Am J Respir Crit Care Med 2009; 180(1): 3-10.

13. Mercado N, Ito K, Barnes PJ. Accelerated ageing of the lung in COPD: new concepts. Thorax 2015; 70(5): $482-489$.

14. Landis SH, Muellerova H, Mannino DM, et al. Continuing to Confront COPD International Patient Survey: methods, COPD prevalence, and disease burden in 2012-2013. Int J Chron Obstruct Pulmon Dis 2014; 9: 597-611.

15. Barnes PJ. Sex differences in chronic obstructive pulmonary disease mechanisms. Am J Respir Crit Care Med 2016; 193(8): 813-814.

16. Roberts NJ, Patel IS, Partridge MR. The diagnosis of COPD in primary care; gender differences and the role of spirometry. Respir Med 2016; 111: 60-63.

17. Chapman KR, Tashkin DP, Pye DJ. Gender bias in the diagnosis of COPD. Chest 2001; 119(6): 1691-1695.

18. Sørheim IC, Johannessen A, Gulsvik A, et al. Gender differences in COPD: are women more susceptible to smoking effects than men? Thorax 2010; 65(6): 480-485.

19. Sin DD, Wu L, Man SF. The relationship between reduced lung function and cardiovascular mortality: a population-based study and a systematic review of the literature. Chest 2005; 127(6): 1952-1959.

20. Persson C, Bengtsson C, Lapidus L, et al. Peak expiratory flow and risk of cardiovascular disease and death. A 12-year follow-up of participants in the population study of women in Gothenburg, Sweden. Am J Epidemiol 1986; 124(6): 942-948.

21. Anthonisen NR, Wright EC, Hodgkin JE. Prognosis in chronic obstructive pulmonary disease. Am Rev Respir Dis 1986; 133(1): 14-20.

22. Menezes AM, Pérez-Padilla R, Wehrmeister FC, et al. FEV ${ }_{1}$ is a better predictor of mortality than FVC: the PLATINO cohort study. PLOS ONE 2014; 9(10): e109732.

23. Oga T, Nishimura K, Tsukino M, et al. Analysis of the factors related to mortality in chronic obstructive pulmonary disease: role of exercise capacity and health status. Am J Respir Crit Care Med 2003; 167(4): 544-549.

24. Celli BR, Cote CG, Marin JM, et al. The body-mass index, airflow obstruction, dyspnea, and exercise capacity index in chronic obstructive pulmonary disease. N Engl J Med 2004; 350(10): 1005-1012.

25. Sin DD, Anthonisen NR, Soriano JB, et al. Mortality in COPD: role of comorbidities. Eur Respir J 2006; 28(6): $1245-1257$.

26. Cardoso J, Ferreira JR, Almeida J, et al. [Chronic obstructive pulmonary disease in Portugal: Pneumobil (1995) and 2002 prevalence studies revisited]. Rev Port Pneumol 2013; 19: 88-95 (in Portuguese).

27. Mascarenhas J, Falcão H, Lourenço P, et al. Population-based study on the prevalence of spirometric obstructive pattern in Porto, Portugal. Respir Care 2011; 56: 619-625.

28. Blanco I, Diego I, Bueno P, et al. Geographical distribution of COPD prevalence in Europe, estimated by an inverse distance weighting interpolation technique. Int J Chron Obstruct Pulmon Dis 2018; 13: 57-67.

29. Ragaišienė G, Kibarskyte R, Gauronskaitė R, et al. Diagnosing COPD in primary care: what has real life practice got to do with guidelines? Multidiscip Respir Med 2019; 14: 28.

30. Duarte-de-Araújo A, Teixeira P, Hespanhol V, et al. COPD: analysing factors associated with a successful treatment. Pulmonol 2020; 26(2): 66-72.

31. International Classification Committee of WONCA, World Organization of Family Doctors. ICPC-2-R International Classification of Primary Care. Revised Second Edition. New York: Oxford University Press; 2005.

32. The Global Iniciative for Chronic Obstructive Lung Disease (GOLD). 2020 Global Strategy for Prevention, Diagnosis and Management of COPD. Available from URL: http://goldcopd.org/gold-reports/.

33. Shahriary A, Panahi Y, Shirali S, et al. Relationship of serum levels of interleukin 6, interleukin 8, and C-reactive protein with forced expiratory volume in first second in patients with mustard lung and chronic obstructive pulmonary diseases: systematic review and meta-analysis. Post Dermatol Alergol 2017; 34(3): 192.

34. Shahriary A, Rahmani $\mathrm{H}$. Need to study of systemic markers changes in acute phase of respiratory complication due to sulfur mustard. Toxin Reviews 2017; 36(3): 261-263.

35. Shahriary A, Ghanei M, Rahmani H. The systemic nature of mustard lung: comparison with COPD patients. Interdiscip Toxicol 2017; 10(3): 114-127.

Tables: 3

Figures: 0

References: 35

Received: 1.09 .2020

Reviewed: 5.10 .2020 .

Accepted: 10.11 .2020

Address for correspondence:

José Augusto Simões, MD, PhD, Assoc Prof.

University Clinic of General and Family Medicine

University of Coimbra

Pólo III - Ciências da Saúde, Subunidade 3

Azinhaga de Santa Comba, Celas

3000-548 Coimbra, Portugal

Tel.: +351924 406127

E-mail: jars@fcsaude.ubi.pt 